\title{
The Functions Of Use Code Switching In English Learning Classroom
}

\section{(Ethnography Communications Research)}

\author{
Eva Fachriyah \\ Fachriyahe@yahoo.co.id
}

The aims of this research is to gain a deep understanding and to knowing the use of code-switching that have done by students and lecturers in interaction when teaching learning in English class. Specifically or as sub-focus in this research was aimed to determine the functions for the use of code switching that is used by both of the speaker and hearer that in this case the interaction between lecturer and students when learning takes place. This research was conducted at the campus of the State Islamic Institute "Sultan Maulana Hasanuddin Banten" at the Faculty of Education and Teaching in English department at the third semester. This study was a qualitative research by using ethnography of communication method. The techniques and procedures of data collection were used such as observation, recordings and transcripts, and interviews. Based on data analysis, the use of code switching in English classroom has got the result for functions of code switching in interaction when the learning take place.

Key words: code switching, English learning, ethnography communication. 


\section{INTRODUCTION}

The issue of linguistic switch in sociolinguistic field of foreign language teaching was a major subject of scientific study in the past. But, recently, code-switching has attracted a considerable amount of attention. Code switching has become an interesting phenomenon to study in particular of language usage in society because it is part of development process and use multiple languages (bilingual). About code choice phenomenon, include code switching became a case of bilingual "We will look mainly at the phenomenon of code-switching in bilingual and multilingual situations."(Wardaugh, 2006).

The reasons cannot be separated from the influence of linguistic diversity in a community of people who eventually intermingled to form a mixture that can be understood by the community in other words that the people who have the language $\mathrm{A}$ and entered by other people who have the language B so that both communities are mixed in a single community. So, naturally the language will have to pass the language development including a double to form code switching.

The relationship with the foreign language teaching learning process especially English subject usually occur the use of code switching, the case occur based on the different backgrounds and reasons as Sert give the state about it that "In ELT classrooms, code switching comes into use either in the teachers' or the students' discourse" (Sert's,2005), and also code switching exist in English classroom and occur in many code variation. English language so important to studied in this state Indonesia by us, here the position English language as foreign language "English is seen less and less as a "foreign" language, and more as an additional language. In other words, learning English is no longer viewed as something optional, but essential." (Tesol, 2008).

At the end, one of the goals of teachers EFL (English Foreign Language) how the students speak English as much as possible, especially when they in the classroom to speak English, as the opinion of Hancock (Hancock, 1997) that "to promote communicative competence, learners must get practice in communicative exchanges in the classroom". So, to improve communication competence in English, teachers must do more exercises in the classroom. For that teachers should also be able to speak English fluently if learning to speak to be effective. 
However, in reality both teachers and pupils/students still perform code switching or code-mixing even at the highest levels of education with a specific concentration has also, for example, in the English department. They require it to the various needs and objectives.

Various researches on code switching that occurs in a bilingual classroom have also improved a lot over the last two decades. The research moved from educational research and classroom interaction style of language teachers. Study of code switching is generally housed within a sociolinguistic opportunities for researchers and linguists to study the common symptoms that occur in a bilingual society and multilingual. Code switching can be examined from various viewpoints such as shape, happening place, patterns, and functions of code switching and code-mixing itself. In this case have described and discussed based on the functions of code switching.

\section{Review of Literature}

Bilingualism or we more often hear the term bilingual, already we know that means is the using of two or more languages or language code. In many sociolinguistics research that examines issues of language codes must be very closely related to bilingualism. Explanation about the concept of bilingualism is always changing. The term was first introduced by Bloomfield (Bloomfield, 1988) in his book "Language" states that "in the cases where this perfect foreign language learning is not accompanied by loss of the native language" (Bloomfield, 1988) its mean that bilingualism is the ability of use two language as well as native speaker or "native like control of two languages" (Bloomfield, 1988).

Bilingual society and multilingual generally tend to switch codes language in their daily activity. Code switching that occurs in the community is often regarded as a strategy conversation. Sometimes these strategies in terms of influence stylistic, which relates to its use in reinforce or weaken the speech acts such as requests, denials, switching topics, elaboration or comments, validation, or clarification (Heller, 1988). Symptoms of code have a value of "naturalness" for particular speech events for the community or bilingual speakers or more. According to Milroy (Milroy, 1999) over the code is the use of multiple languages alternately by bilingual speakers / various languages. 
In this case many experts have given clear define about code switching and make difference with the other terms, one of them Gumperz state that code switching is "the juxtaposition within the same speech exchange of passages of speech belonging to two different grammatical systems or sub-systems"(Gumperz, 1982) and for more complete Milroy argue that "The term "code-switching" can describe a range of language (or dialect) alternation and mixing phenomena whether within the same conversation, the same turn, or the same sentence-utterance."(Milroy, 2003) Then, Cecilia in Seba give the define about code switching for more simple, state that "code-switching - the alternating use of two (or more) languages-is a natural occurrence in the speech of bilingual individuals that," (Seba, Mahootian, and Johnson, 2012).

In another part, Milroy mention that the code switching is the alternative use of two or more languages by bilingual speakers / multiple languages in one conversation. In this case Milroy see that code switching a manner or form of communication that is common place in a bilingual society and a variety of languages. In contrast, in the process of bilingual education and foreign language code switching is not familiar and natural as in society bilingual / multi-language, but more managerial. In a learning processes of code to act more as a tool to manage and facilitate interaction and learning. (Heller, 1988) plainly says that the code switching is the process of using more than one language in one episode of communication. In this case it does not require the balancing mastery of two languages or more by speakers who is switching of codes.

Code-switching in foreign language classroom has recently been the subject of considerable debate. When researchers address the issue, especially the use or the role of the L1 and the TL, there appear to be two opposing language attitudes among them, target language exclusivity and the opposition.

\section{METHOD}

This study is a qualitative research with the intent to collect the data, process the data, analyze data, and present data objectively about the interaction of code switching in teaching English to students of English department of State Islamic Institute "Mulana Sultan Hasanuddin" Banten. Thus, the exact method used in this study is an ethnographic method of communication based on the theory Hymes developed by Saville-Troike with a pragmatic approach. The procedure of research by observation, recording, transcription of data, the analysis of data, and a research report. 
The primary data that used is the phenomenon of code switching in teaching learning interactions that occur when teaching and learning process English classroom in English department at the State Islamic Institute "Sultan Maulana Hasanuddin" Banten. The primary data source is the English Department student interaction in English classroom. Meanwhile, secondary data is books or documents relevant to the focus of research.

Procedures and data recording is an effort made to obtain data in the field. It requires a variety of ways in order to achieve the research objectives. The procedure of collecting data through observation, recording, and interviews. In connection with the foregoing, the steps to analyze the data to create categories based on the communicative situation, communicative events, and communicative action.

\section{THE RESULT AND DISCUSSION}

The result in terms of functions of code-switching to Indonesia may support the previous finding (Macaro, 1997), which suggest the switching to L1 necessarily serves some basic functions which may be beneficial in foreign language learning environments. The data from classroom recordings reinforce the views on the functional uses and enrich the data from some reviews. In this part, will firstly calculate the functions of the use of code switching to Indonesia and then adopt the samples from the collected data to illustrate the functions of code-switching to Indonesian.

Based on the analysis functions of code switching in English classroom have occurred between students and lecturers in English program can be taken summaries they are: (1) the function for clarification, (2) the function of reiteration or repetition, (3) the function of explanation, (4) the function for asked, (5) the function for translate, (6) the function for check understanding, (7) the function for emphasize on some languages element, (8) the function for inferences, (9) the function for develop vocabularies, (10) the function to discuss student's task, (11) the function to give feedback, (12) the function to memorize, (13) the function to manage class, and (14) the function to entertainment.

Next, here will provide the description of samples from the functions of code switching;

The first, the function for clarification, shape of code switching from English to Indonesian language conducted by teacher and learner in English class when teaching 
English in progress intended to provide clarification or confirmation of an explanation, statement, information, questions or statements in order to do not happen misunderstanding in terms of capturing the intent of a speech. In this case based research of Aichuns (Aichuns: 2007) underlines that:

"teachers' concerns for unfamiliar vocabulary or expression often prompt them to code-switch. When the teacher is not sure whether the students know the meaning of the target language word or expression in question, then it is common for him/her to offer the Chinese translation for clarification."

The use of code switching have the means that speakers do the confirmation or clarification on their speech in English language as a code base that is used in these interactions for a variety of things speakers felt the need to transfer the code into Indonesian as a form of clarification on their speech previously in English.

Second, the function of reiteration or repetition, In do the code switching to function reiteration, the speaker intends to repeat the speech into Indonesian in the form of a sentence or phrase, repetition is done to give emphasis to a speech in terms of the elements of language that is used to align the two forms of meaning different languages, so that partners said gain an understanding of a phrase spoken by the speaker in his interactions.

The importance of the function of repetition becomes a reason for someone to transfer the code switch as revealed by (Flyman-Mattson and Burenhult : 1999) that "the repetition in the first language can be either partial or full and is often expanded with further information, but more frequently code-switching is used as a repetition of the previously uttered sentences" in general, the looping structure on the transfer function of the code is preceded by the target language, and according to Eldridge that basically the repetition is emphasis on a message to be delivered following quotation"messages are reinforced, emphasized or clarified where the messages have already been transmitted in one code but not understood" still in same case (Gumperz:1982, Kamwangamalu and Lee 1991, Brice 2000 the function of repetition in code switching is to check understanding.

Third, the function of explanation, redirection code language made by speakers in the interaction turns out there are functions to explain, both of explain the information or a statement previously discussed using basic English code later explanation use 
Indonesian speakers use a code, example one their speech as below. Moreover, in the teaching of grammar.

(1) S1 : Ya, kata subject bertemu dengan kata subject lagi menjadi compound subject. Kata verb dari kata kerja bertemu dengan kata kerja lagi disebut compound verb..okay Tika..

Okay, for negative sentence is use "not" ..is just use "not" in for the sentence. For example.

$\mathrm{S} 2$

Book..book..bukan dook..

Nah, this is negative sentence.

Book..bukan dook

S3

S2 :

S3 :

In the conversation, the speaker do the code switching to Indonesian language. That can be seen on the statement "Ya, kata subject bertemu dengan kata subjek lagi menjadi compound subject. Kata verb dari kata kerja bertemu dengan kata kerja lagi disebut compound verb..okay Tika.." the sentence is not only explanation from a question and also the answer. And in the explanation speaker use Indonesian language it's mean the speaker do code switching which has the function as explanation.

Fourth, the function for asked, when the speakers interact the base code that is English language then the speaker want to ask use Indonesian language not use English language in that time the speaker do code switching that has the function for asked because when the speaker want to ask he/she use Indonesian language, as shown in the following speech as an example. 
(2) L : Iya..never mind ya because practice makes perfect.Kira kira ada yang kurang tepat pengejaannya? Chicago or Cicago tadi?

Cicago...

S : Chicago or Cicago?

Chicago

L :

S :

In the conversation above can be seen clearly on the sentence bold there is a question use Indonesian language that is "kira-kira ada yang kurang tepat pengejaannya?" the question spoken after the speaker speak use English language and then she/he switch the code when the speaker speak use Indonesian language. So, in the conversation contain the function of code switching for asked.

Fifth, the function for translate, form of code switching from English into Indonesian carried by speakers in interactions intended to translate a statement or question because the speaker feels need to translate their speech order hearer understand the intent of the conversation in order to avoid misunderstandings.

Sixth, the function for check understanding, form of code switching from English into Indonesian or otherwise have a function to review previously taught material that it is also done to check for student understanding on a matter that has been learned in the classroom as a benchmark for determining the level of students' understanding of the final value.

(3) L : Okay, sometimes a concluding sentence reminds the readers of the points in topic sentence. Di ulang lagi di ulang lagi ya..sama aja dengan yang pertama kali di pelajarai dulu ya. So di pharaphrase ya...kalimat yang di atas itu topic sentence nya, topicsentence, supporting sentence terus di akhir nah topic tadi di summary di pharaphrase dengan bahasa yang berbeda di pharaphrase. Jadi di singgung sedikit ya yang topic sentence nya tadi untuk dijadikan sebagai concluding sentence.. 
Sentence

$\mathrm{L}$

$\mathrm{S}$

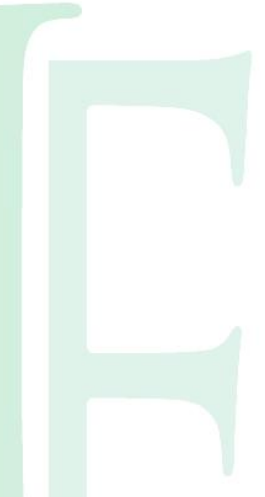

In the conversation can be conclused that the speech has means do the review the material before. In addition, there is an expression that the material had been previously studied in expression"Di ulang lagi di ulang lagi ya..sama aja dengan yang pertama kali di pelajari dulu ya." Speakers also review the material use code switching into Indonesian. But still use the basic code when trying mention terms related to the lecture material.

Seventh, the function for emphasize on some languages element, Important messages can be reinforced or emphasized when they are transmitted in the L1 (Macaro) form of code switching that occur in an interaction when teaching in the class, speakers do the code when trying to explain to emphasize the elements of language specific related teaching materials in English, speakers felt need to switch the code to avoid 
misunderstandings and between speakers and hearer have the same understanding of the specific linguistic elements related to the material because of the linguistic elements of a theoretically, so, the speakers need to code switch into the language that more quickly understood by both sides to interact.

Eighth, the function for inferences, form of code switching by functionality makes conclusions made in interacting it means speakers using basic code that is English when explaining a material such statements, information, questions and so forth. However, when they want to conclude the speakers explain use code switching into other languages beside English. So, the form of code switch has the function of making conclusions (inferences).

Nineth, the function for develop vocabularies, form of code switch means those speakers do the code switching and the conversation discuss about vocabulary then the material be developed in interpret.

Tenth, the function to discuss student's task, form of code switch carried by the speakers can also be said have a function to discuss the assignment of students, in the event the speakers do code switch into other language beside English, in the conversation the speakers discuss student's task that has been given by the teacher in order the students understand about the instruction the teacher code switch in the interaction with students use Indonesian language.

Eleventh, the function to give feedback, form of code switching from English to Indonesian language intended to give feedback. In the conversation the speakers switch codes. One of the activities in teaching is providing feedback that is usually conducted by a lecturer to the students to determine the extent students understand about the material being studied and it is necessary so that students know the successes and mistakes made by the students. In conversation provide feedback the speaker in this case use code switch to students in order to more quickly understand and capture the intent of the question of their lecturer.

Twelfth, the function to memorize, in the classroom the lecture usually remind students about a material or the roles have been deal, but the students usually forgot about or otherwise lecturers will remind students of a material or rules. So, the point in learning can remind each other, in the conversation often occurs code switching. 
Three tenth, the function to manage class, in teaching learning activities, there many activities that is not also the transfer of knowledge as the main aim but also there are other activities that are supporting learning activities are the management of the classroom for learning to walk in an orderly and conducive, manage the class lecturers with students to create a rule together / making agreements that learning takes place is conducive, and how teachers in manage class sometimes there is a language selection in that condition they are often code switching in Indonesian language "Some teachers resorted to L1 after having tried in vain to get the activity going in L2”. (Macaro, 1997) in the same case (Choong, 2006) assert that "Some reasons for using the L1 in the classroom are to convey and check the comprehension of lexical or grammatical forms and meanings, to give directions, and to manage the class."

In that condition there is interaction that not infrequently they often switch code into Indonesian, because of various factors, one of them because they feel in class in that condition not part of the transfer of knowledge. As example as below.

(4) S : (talking something)

L Y Ya di tahan tahanin aja lah. Next week you have to come earlier ya..biar..

Biar gak di serobot orang lain.

S :

In providing instruction to students about classroom conditions uncomfortable for the next lecturer suggested to students in order to arrive early in order to get comfortable classrooms, lecturers switching codes into Indonesian language because it is considered more effective and efficient given the time which is not much so lecturer do not want spent only for such instruction.

Four tenth, this is the last the function in this study that is to entertainment. to relieve boredom, relieve tension or simply to better familiarize themselves with each other in the educational situation sometimes both lecturer and students make a joke with each other, in jest that they will feel better when using the Indonesian meaning here the events of code switch into Indonesian language. 
In this study, researchers also encountered resistance particularly when data collection at the sites. One of them is not all lecturers who teach the English language would be recorded the process of learning activities. So only a few lecturers who are willing that researchers record the learning process. In addition, at the beginning of the study the students feel disturbed by the presence of investigators. Thus, the researchers used another strategy as a solution.

\section{CONCLUSSION}

In language teaching, in this case the English language often appears a phenomenon related to sociolinguistics one of them is over the code switching, which is a code over the use of two languages in a single interaction events. In English teaching the use of code into Indonesian frequent. Although some experts disagree with the use of code because it is perceived to have low prestige.

However, based on the results of the analysis of the use of code language instruction has several functions to support the effectiveness of the learning process takes place, the function of which for clarification or confirmation, as reiteration, explanation, questioning, translating, checking understanding, the emphasis on the elements of language specific, making inferences, develop vocabulary, discuss assignments, provide feedback or feedback, alerting, managing a classroom, doing entertainment / expense.

This research is expected to be useful especially for teachers in the field of language determines the language attitudes and understanding in terms of the phenomenon of code switching in the field of sociolinguistics.

\section{REFERENCES}

Aichuns, L.(n.d.) (2007) Teacher Code switching between English and Chinese in English as a Foreign Language. Retrieved on March 28, 2007, from the World Wide Web: http:// www.google.com. Or liumarie 712@ Yahoo.com.

Bloomfield, Leonard. (1935). Language. London:Allen \& Unwin.

Crystal, David. (1988) The cambridge Encyclopedia of Language. Cambridge: Cambridge University Press 
Brice, A. \& Roseberry-Mckibbin, C. (2000). Choice of Language in Instruction: One Language

Two.http://www.google.com/search?q=cache:1aTV8B_xsvkJ:journals.sped.org/EC/Arc hive_Articles/VOL.33NO.4MARAPR2001_TEC_Article2.pdf+classroom+discourse+in +bilingual+context\&hl=en

Cook, Vivian (2008). Second Language Learning and Language Teaching, UK: Hodder Education

Fantini, A. (1985). Language Acquisition of a bilingual Child. A Sociolinguistic Perspective. Sandiego: College Hill Press

Gumperz, John J. (1982). Discourse strategies. (Cambridge: Cambridge University Press

Hancock. Mark. (1997). Behind classroom code-switching, Layering and language choice in L2 learner interaction, TESOL Quarterly 31 (2), 1997

Heller, Monica (2007). Bilingualism: a Social Approach (New York: Palgrave MaCMillan

Martin-Jones, Marylin.(1997). Code-switching in the Classroom. Dalam Milroy, Lesley \& Peter Muysken (Editor.). One Speaker, Two Languages. Cambridge: Cambridge University Press

Macaro, E. (1997). Target language, collaborative learning and autonomy. Clevedon: Multilingual Matters

Milroy, Lesley and Matthew Gordon.(2003). Sociolinguistics: Method and Interpretation, (England: Blackwell Publishing

Mattsson, Flyman A. \& Burenhult, N.(1999). Code switching in Second Language Teaching of French. fromhttp://www.google.com/search?q=cache:GbFBmAtk8TAJ:www.ling.lu.se/dissemin ations/pdf/47/Flyman_Burenhult.pdf+classroom+discourse+in+bilingual+context\&hl=e n.h.11 (Retrieved 28 December 2015)

Ronald Wardhaugh. (2006). An Introduction to Sociolinguistics (five edition). Blackwell Publishing. 
Reyes, I. (2004). Functions of code-switching in schoolchildren's conversation. Bilingual Research Journal, 28 (1), 2004

Sert, Olcay. (2005) The Functions of Code Switching in ELT Classrooms. The internet TESL Journal XI, 8, http://iteslj.org/Articles/Sert-CodeSwitching.html (last accessed on June 23, 2012)

Sebba, Mark, Shahrzad Mahootian and Carla Jonsson. (2012). Language Mixing and Code-Switching in Writing, New York: Routledge

Tesol. (2008). Position Statement on English as a Global Language, Approved by the Board of Directors March, Web http://www.tesol.org (Retrieved 12 februari 2015)

Zentella, A. C. (1997). Growing up bilingual. Maiden, MA: Blackwell 